\title{
ENTRE A INSUSTENTABILIDADE E A FUTILIDADE: A JURISDIÇÃO, O DIREITO E O IMAGINÁRIO SOCIAL SOBRE O JUIZ
}

\author{
Angela Araujo da Silveira Espindola ${ }^{1}$
}

\begin{abstract}
RESUMO: Este "ensaio" pretende tecer uma abordagem despretensiosa sobre o problema da falta de sentido do direito e, consequentemente, da jurisdição, a partir da problemática em torno da decisão judicial, do papel (social) do julgador e do modo de produção do próprio direito, conduzida pelo filtro do movimento law and literature. A reflexão busca inspiração nas obras de Milan Kundera para discutir as representações do direito e do imaginário social sobre o juiz, tecendo críticas ao normativismo legalista e ao funcionalismo jurídico enquanto modelos de realização da jurisdição e sinalizando o jurisprudencialismo como contraponto aos modelos anteriores, o qual assume o paradigma da jurisdição centrado no juízo, e não na subsunção lógico-dedutivista ou na simples decisão.
\end{abstract}

Palavras-ChaVes: jurisdição, estado, direito e literatura.

\section{NOTAS INTRODUTÓRIAS: PORQUE ENTRE A FICÇÃO E A REALIDADE HÁ O SENTIDO}

Este "ensaio" pretende tecer uma abordagem despretensiosa sobre o problema da falta de sentido do direito e, consequentemente, da jurisdição, a partir da problemática em torno da decisão judicial, do papel (social) do julgador e do modo de produção do próprio direito, conduzida pelo filtro do movimento law and literature

Doutora e Mestre em Direito Público pela Universidade do Vale do Rio dos Sinos (UNISINOS). Professora Adjunta do Departamento de Direito da Universidade Federal de Santa Maria (UFSM). Professora do Programa de Pós-Graduação em Direito e Curso de Graduação em Direito da UFSM. Editora da Revista Eletrônica do Curso de Direito da UFSM. Membro da Associação Brasileira do Ensino do Direito (ABEDi). MembroFundadora da Rede Brasileira Direito e Literatura (RDL). Advogada. Santa Maria, RS, Brasil. $\quad$ CV Lattes: http://lattes.cnpq.br/8242346710380248. E-mail: ange.espindola@gmail.com 
Primeiro, há que se explicar a opção pelo título Da insustentabilidade à futilidade, que resulta da inspiração de duas obras de Milan Kundera (1984; 2014). O romance $A$ insustentável leveza do ser elege o contexto de 1968 para discutir a relação peso/leveza existente na dualidade ontológica de cada ser, valendo-se muito da perspectiva existencial e dos conteúdos filosóficos de Nietzsche e Parmênides. O romance $A$ festa da insignificância trata sobre o esvaziamento de sentido e do significado da insignificância. O título deste ensaio é, portanto, uma paráfrase, não só mecânica, mas também construtiva, desses dois romances de Kundera (1984; 2014), sinalizando o texto literário como instrumento de compreensão mais profunda do direito e sua problemática que aqui é objeto de reflexão. A literatura traz luz aos problemas jurídicos, sobretudo àqueles relacionados com a retórica e com as atitudes morais: direito e literatura interagem de diversas formas (Trindade, 2013). O problema que aqui se pretende discutir é acerca das representações do direito e do imaginário social sobre o juiz, o qual nos conduz inevitavelmente para uma reflexão acerca da crise de sentido do direito e da jurisdição ${ }^{2}$.

\section{A LEVEZA E O PESO DA JURISDIÇÃO: SUA (IN)SUSTENTABILIDADE}

Tratar a jurisdição, sua concepção e sua função é também discutir sobre o perfil do Estado. Antes de se defender um sentido de jurisdição, é preciso observar o Estado que se possui. Não é por acaso, portanto, que as reflexões sobre o Estado moderno e suas implicações na contemporaneidade consistem em temática recorrente, em especial, no contexto de um mundo globalizado. As mudanças estruturais da política nacional e internacional provocaram e continuam provocando profundas transformações no Estado, seja no que diz respeito às funções estatais, aos arranjos institucionais, à base social, à legitimidade política, à autonomia ou, ainda, no que diz respeito à promoção e proteção de direitos.

Desde longa data, o perfil do Estado se reflete no modelo de produção do direito e na jurisdição e, claro, no papel a ser desempenhado pelos seus protagonistas, em especial, o juiz. Assumindo a modernidade como marco para o surgimento do Estado (moderno), tem-se que é só a partir de então

2 Sobre a proposta da "refundação" da jurisdição, ver Espindola, 2012. 
que se pode falar em uma função nitidamente jurisdicional. $\mathrm{O}$ surgimento da jurisdição estatal coincide com a formação do Estado moderno, vinculando-se, portanto, à leveza e ao peso de seus compromissos. Ambos Estado moderno e jurisdição estatal - nascem em oposição à sociedade medieval pluralista, que compreendia diversas fontes de direito e formas de resolução de conflitos, caracterizando-se pela multiplicidade e descentralização do poder. Ergueu-se, assim, sobre os escombros do medievo, o Estado moderno, centrado no absolutismo3 ${ }^{3}$ convertido posteriormente ao liberalismo, pretendendo-se, após, um Estado social e, mais recentemente, um Estado Democrático de Direito (Streck, 2014, p. 44), com base em princípios e garantias constitucionais.

As grandes transformações que se seguiram a partir de então (no âmbito da política, da economia, da cultura, etc.) resultaram na nova sociedade que passou a exigir novo Estado a cada nova fase. O constante e dinâmico processo evolutivo do Estado moderno foi marcado primeiramente pela presença do poder ilimitado, absoluto e perpétuo, concentrado nas mãos do monarca, justificado ideologicamente na teoria do direito divino dos monarcas ${ }^{4}$. Os intelectuais da modernidade, sobrepujando a mentalidade medieval, alinhavaram uma nova ideologia

3 Sob os escombros da sociedade feudal, moldado sob a perspectiva das monarquias absolutistas, emerge o Estado Absolutista. Nas palavras de Miranda (2002), o Estado estamental da sociedade medieval foi substituído pelo Estado absoluto, o qual afirmava o princípio da soberania, não aceitando qualquer interposição a separar o poder do Príncipe e os súditos. O Estado, em sua primeira versão absolutista e enquanto instituição centralizada, foi fundamental para os propósitos da burguesia no nascedouro do capitalismo, quando esta, por razões econômicas, abriu mão do poder político, delegandoo ao soberano. Na virada do século XVIII, entretanto, essa mesma classe não mais se contentava em ter o poder econômico; queria, sim, agora, tomar para si o poder político, até então um privilégio da aristocracia (Zippelius, 1997, p. 136). Assim, apesar de o Estado Absolutista ter como um de seus alicerces o apoio da burguesia aos monarcas, o ente estatal não foi controlado pela burguesia. Esta não ocupou o poder político do Estado Absolutista, restringindo-se ao domínio do poder econômico. A partir do século XVIII, a burguesia não estava mais satisfeita em deter apenas o poder econômico, reivindicando o espaço político para fazer par ao poder econômico já conquistado. Testemunha-se, então, uma nova tensão: a tensão entre o político e o econômico (Streck, 2014, p. 44). Esse aspecto pode ser ilustrado citando que "o absolutismo do poder monárquico é alcançado, ao menos em teoria, na medida em que o príncipe não encontra mais limites para o exercício de seu poder nem dentro nem fora do Estado nascente" (Bobbio, 1998, p. 429).

4 "O poder que se aglutina neste momento reflete a ideia de sua absolutização e perpetuidade. Absoluto, pois não sofre limitações sequer quanto à duração e, por isso, também perpétuo. Resta, apenas, adstrito às leis divinas e naturais" (Bolzan de Morais, 2008, p. 29). 
política, legitimando o absolutismo5. O direito, àquela época, identificava-se com a 'vontade do príncipe': L'Etat c'est moi. Apesar de o Estado ter como única fonte jurídica a lei, esta não vinculava o príncipe, que estava acima e não limitado por ela.

Diante das exigências por uma autonomia política e mais respeito às liberdades individuais, especialmente as religiosas, o edifício absolutista começa a ruir. Se o Estado absoluto emerge para opor-se ao modelo organizacional da sociedade medieval e ao poder feudal; o Estado liberal, que vai sucedê-lo, consagrou-se pela firme tentativa (e pelo sucesso) de frear aquele poder ilimitado, absoluto e perpétuo, característico do absolutismo (do rei). O liberalismo surge como a melhor resposta contra o absolutismo (do soberano). A autonomia da vontade recebe destaque bastante especial, expressando a limitação da autoridade por meio do dogma da separação dos poderes e do princípio da legalidade. Elege-se um novo soberano para o Estado Moderno, qual seja, a assembleia parlamentar (ou seja, a lei). O primeiro palco dessas modificações foi a França: a assembleia parlamentar francesa substituiu o rei na tarefa de legislar. O absolutismo do rei - um absolutismo institucionalizado - foi decapitado e o absolutismo da assembleia parlamentar francesa - um absolutismo velado - ensaiava seus primeiros passos ${ }^{6}$. Mesmo que não se adote a perspectiva de uma continuidade do espírito monárquico nessa supremacia da lei, é praticamente inegável que se atribuiu à lei a responsabilidade de renovar o sistema jurídico da época. Não se trava de uma lei, considerada a partir de um sentido substancial, mas antes de um sentido (e peso) formal. Era hora da primeira revolução do Estado de Direito 7 de que trata Luigi Ferrajoli

5 Dentre os principais teóricos do absolutismo, destacam-se: Nicolau Maquiavel (14691527), Jean Bodin (1530-1596), Hugo Grotius (1583-1645), Thomas Hobbes (1588-1619) e Jacques Bossuet (1627-1704).

6 Nessa quadra, o caminho trilhado pelo parlamento inglês será outro: o absolutismo é erradicado, e a lei, conjugada a valores, dará origem ao sistema da common law (Zagrebelsky, 2003; Zagrebelsky, 2005).

7 A expressão primeira revolução é aqui empregada no sentido utilizado por Luigi Ferrajoli. Na perspectiva de Ferrajoli, existem dois sentidos para o Estado liberal recémformado, ou seja, dois sentidos para o princípio da legalidade que o apóia: um sentido fraco (formal) e um sentido forte (substancial). Aquele se refere a "cualquier ordenamiento en el que los poderes públicos son conferidos por la ley y ejercitados en las formas y con los procedimientos legalmente establecidos" (2003, p. 187), ao passo que um sentido mais forte refere-se "sólo aquellos ordenamientos en los que los poderes públicos están, además, sujetos a la ley (y, por tanto, limitados o vinculados por ella), no sólo en lo relativo a las formas, sino también en los contenidos" (2003, p.187). No caso, o princípio da legalidade, nesse período inaugural do Estado Liberal, assume-se com um 
(2003), ou seja, da afirmação da onipotência do legislador. Erigia-se, nesse caldo, o princípio da legalidade formal como critério de identificação do direito: sucessora do rei, a legalidade impunha limites às liberdades e arbitrariedades (do Estado). Para atender a essa supremacia da lei, o dogma da separação dos poderes, também fixado pela Revolução Francesa, consolidou o poder legislativo como o protagonista do Estado. Chaïm Perelman (1996, p. 517) lembra do référé législatif, instituído através do Decreto de 24/o8/1790, ainda no calor da revolução francesa: caso o juiz tivesse qualquer dúvida quanto à interpretação da lei, deveria, necessariamente, recorrer ao legislador. O objetivo era "impedir que o juiz interviesse como legislador; mesmo para melhorar o direito, o juiz não deve completar a lei nem interpretá-la” (Perelman, 1996, p. 520). As decisões judiciais, os atos administrativos e os negócios jurídicos não eram vistos como atos de criação do direito. Na verdade, não podiam criar direitos, mas, apenas, aplicar um direito já pré-dado, predefinido pelo legislador.

O direito, já predefinido pelo legislador, representava, assim, a vontade geral rousseauniana - la volonté general. Ao mesmo tempo que se proclama a soberania da nação, estipula-se que a lei é a expressão da vontade geral e que todos os cidadãos têm o direito de concorrer para a sua formação (Lefort, 2003, p. 69). Porém, o Estado é o responsável pela volonté general ${ }^{8}$. Não só na França, mas em toda a Europa do século XIX, o

sentido fraco, formal, "como criterio exclusivo de identificación del derecho válido" (2003, 190), alterando os paradigmas do direito e da jurisdição. A primeira revolução, nesta linha, representa a onipotência do legislador, submetido a vínculos exclusivamente formais (princípio da legalidade formal), e a segunda revolução representa o constitucionalismo e a positivação dos direitos fundamentais enquanto limites substanciais para a lei (princípio da legalidade substancial). Ambos os perfis do Estado de Direito, seja o primeiro (fraco), seja o segundo (forte), resultam de transformações paradigmáticas, no que se refere à natureza e estrutura do Direito, da Ciência Jurídica, bem como, da Jurisdição (Ferrajoli, 2003).

8 Para Rousseau, "só a vontade geral pode dirigir as forças do Estado de acordo com a finalidade de sua instituição, que é o bem comum, porque, se a oposição dos interesses particulares tornou necessário o estabelecimento das sociedades, foi o acordo desses mesmos interesses que o possibilitou" (Rousseau, 1996). Em que pese a crítica que se faz contra a vontade geral rousseauniana, há que se enfatizar a repercussão positiva desse conceito, como fonte permanente de inspiração. A teoria política de Rousseau, baseada na vontade geral, não se manifestou apenas na Revolução Francesa, mas inspirou muitas das teses republicanas e igualitárias no movimento de independência norte-americano e nas constituições das treze ex-colônias inglesas. Nesse sentido, ressaltando a contribuição da teoria da vontade geral, consultar: Salinas Fortes, 1989. Na verdade, a ideia da volonté generale surgiu para cuidar de um problema político como argumento para a Revolução, e não como um problema filosófico. 
poder do parlamento se faz sentir de modo absoluto. A ideia da onipotência do parlamento converteu-se em um verdadeiro mito jurídico.

Estavam semeados os valores de um Estado Liberal, calcado na liberdade individual, na igualdade formal, na não-intervenção estatal, na separação dos poderes, fortemente influenciado pelo Iluminismo e marcado pelo positivismo jurídico, resultando no princípio (formal) da legalidade e na consequente subordinação do executivo e do judiciário ao legislativo, ou seja, na supremacia da lei e na simplificação das atribuições e poderes do judiciário. A supremacia da lei, portanto, reflete a transformação do papel do Estado na sociedade, bem como o papel do Direito/Lei enquanto meio de regulação estatal. A influência que esse cenário exerce sob a concepção de direito e da jurisdição é flagrante: tem-se nela uma função voltada eminentemente para dar atuação aos direitos privados violados, facilmente convertidos em valores pecuniários. Na verdade, a preocupação principal, no cenário do Estado liberal, é com a construção de uma jurisdição atenta para os direitos privados violados.

Para Scaff (2001), não se trata de um Estado absenteísta por ordem natural, mas sim por imposição dos seus dirigentes. A partir de então, deuse a estatização da produção normativa, cujo grande marco foi o Código Napoleônico, de 1804, servo dos objetivos do Estado Liberal. Prevalece a concepção de um poder estatal limitado, controlado, com "dever de obediência a certas normas jurídicas, cuja finalidade é impor limites ao poder e permitir, em consequência, o controle do poder pelos seus destinatários" (Sundfeld, 1992, p.35).

Na verdade, o Estado Liberal, cuja semente foi burguesa, adotava a mesma retórica do Estado Absolutista, particularizada pela fundamentação da soberania não em Deus (poder divino do monarca), mas no povo. $\mathrm{O}$ Estado Liberal Mínimo representou a primeira forma de Estado de Direito9,

9 A locução Estado de Direito foi cunhada, pela primeira vez, na Alemanha, na obra de Weicker, publicada em 1813 (Hayek, 1991). Ao abordar a temática sobre o Estado de Direito, Canotilho refere que "contra a ideia de um Estado de Polícia que tudo regula e que assume como tarefa própria a prossecução da felicidade dos súditos, o Estado de Direito é um Estado Liberal de direito no seu verdadeiro sentido. Limita-se à defesa da ordem e segurança públicas (Estado de Polícia, Estado Gendame, Estado guardanoturno), remetendo-se os domínios econômicos e sociais para os mecanismos da liberdade individual e da liberdade de concorrência. Nesse contexto, os direitos fundamentais liberais decorriam não tanto de uma declaração revolucionária de direitos, mas do respeito de uma esfera de liberdade individual" (Canotilho, 1999, p. 92-93). 
concebido como aquele que realiza suas atividades subordinadas ao direito $^{10}$ (identificado com a lei), atuando em conformidade com a ordem jurídica. Foi esse o cenário do movimento de codificação presenciado pela modernidade, que consolidou a tradição jurídica romano-canônica. Assim, o modelo liberal formaliza-se como Estado de Direito, contrapondo-se ao modelo absolutista; e os valores liberais vão alimentar o movimento da codificação e a cultura jurídica europeia e dos demais países que recepcionaram ou foram influenciados pela doutrina da Europa Continental.

$\mathrm{O}$ direito no Estado Liberal, diz Roth, destinava-se à proteção dos direitos dos indivíduos contra toda pretensão de interferência do Estado em sua vida privada. "Ele garante ao cidadão, com força se necessário, o uso e o respeito de suas liberdades privadas" (Roth, 1996, p. 19-20); protegendo o direito de propriedade, da liberdade de comércio e de indústria e da liberdade de contratar. Funda-se, sobretudo, contra o direito do Estado e assegura a regulação espontânea da sociedade.

Toda a concepção de direito e de jurisdição idealizada no contexto do Estado Liberal foi o resultado da afirmação da onipotência do legislador, ancorada no princípio da legalidade formal (Ferrajoli, 2001, p. 53) e na eliminação das tradições jurídicas do Absolutismo e do Ancien Régime. $\mathrm{O}$ objetivo era vincular o direito e, em especial, o exercício do poder pelos juízes à estrita legalidade formal. O direito, personificado na figura do juiz, falava por meio da bouche que pronnonce les paroles de la loi, reduzindo-se à lei, elevada a ato supremo. A jurisdição resumia-se à atividade meramente declaratória.

A autovinculação e a autolimitação jurídica do poder estatal, portanto, impuseram-se cada vez mais, fomentando o movimento constitucionalista do século XIX e a afirmação do caráter plenamente normativo da Constituição dos Estados, considerada instância jurídica superior, símbolo maior do poder soberano. Importante apontar o liberalismo enquanto um legado do Iluminismo, uma tentativa de substituir a religião, a ordem e o classicismo pela razão, pelo progresso e pela ciência, espalhando-se pela

10 Segundo Ferreira Filho, "é ao direito que o Liberalismo, descendente direto e imediato do iluminismo, confia a tarefa de limitar, instituir e organizar o Poder, bem como de disciplinar a sua atuação, sempre resguardando-se o fundamental: a liberdade, os direitos do homem" (1999, p. 3-4). 
Europa, em meados do século XVIII'11. Os ingredientes liberais e iluministas coincidem.

Os liberais proclamavam o individualismo e as liberdades individuais, eminentemente a liberdade de movimento e de comércio. O Liberalismo "torna-se a expressão de uma ética individualista voltada basicamente para a noção de liberdade total que está presente em todos os aspectos da realidade, desde o filosófico até o social, o econômico, o político, o religioso etc”. (Wolkmer, 1989, p. 92-93)

As importantes conquistas liberais - liberdade religiosa, direitos humanos, ordem legal, governo representativo responsável e a legitimidade da mobilidade social - foram preservadas com o advento da democracia no Ocidente industrial, a partir da década de 1870 . O século XIX foi a idade de ouro do movimento liberal, porém nem todas as conquistas democráticas resultaram de forças explicitamente liberais e vários foram os perfis assumidos pelo liberalismo, que teve como principais padrões o liberalismo de paradigma inglês e o liberalismo de paradigma francês (Merquior, 1991).

$\mathrm{Na}$ perspectiva de Macridis (1982, p.38), três núcleoscompõem o liberalismo: o núcleo moral12, o núcleo político ${ }^{13}$ e, por fim, o núcleo

11 Os contornos do iluminismo foram ditados por Voltaire, Diderot, Hume, Adam Smith e Kant, para citar alguns. A doutrina do iluminismo, fortemente caracterizada pelo racionalismo e pela aversão ao absolutismo e mercantilismo, permitiu a discussão sobre direitos humanos, governo constitucional e liberdade econômica e, sobretudo, serviu de alicerce para o Estado liberal, assumido como república representativa constituída pelos três poderes (executivo, legislativo e judiciário). A partir da concepção de tempo, assumida na presente pesquisa, é razoável imaginar uma crítica aos ideais liberais e iluministas que alimentam, ainda hoje, o paradigma racionalista e o paradigma liberalindividualista-normativista. No entanto, não se pode negar a contribuição desses movimentos para aquele período da história e a evolução em termos políticos e filosóficos. $\mathrm{Na}$ verdade, trata-se, nos exatos limites deste trabalho, de avançar-se da crise (paradigmática) à crítica, em que a crise assume o significado (positivo) de ruptura com o passado e compreensão do presente, no sentido da construção de um futuro (possível). Negar a crise, portanto, é ocultar a temporalidade e deixar-se seduzir pela tentação do óbvio.

12 O núcleo moral, diz Macridis, "contém uma afirmação de valores e direitos básicos atribuíveis à natureza de um ser humano" (1982, p. 39-40). A proteção do indivíduo contra o governo, em especial, no que se refere à liberdade pessoal (liberdade de pensamento, de expressão), bem como à liberdade social (oportunidades de progredir, acesso às oportunidades, mobilidade social), está ligada ao núcleo moral do liberalismo. Nessa ótica, a defesa dos direitos humanos é um dos velhos gritos de guerra do liberalismo.

13 O núcleo político ou político-jurídico envolve o consentimento individual, a representação e o governo representativo, o constitucionalismo e a soberania popular. $\mathrm{O}$ pensamento contratualista é, portanto, o seu alicerce, eis que: o consensualismo individual é a fonte da autoridade do Estado; a representação significa a atribuição de autoridade à legislatura, eleita pelo povo, legitimadora das decisões do Estado em nome do majoritarismo. $O$ constitucionalismo, por sua vez, limitava explicitamente o poder do Estado, mas também atribuiu responsabilidades aos governantes em relação aos governados, protegendo o 
econômico ${ }^{14}$, justificando a tríplice composição do liberalismo clássico, qual seja: a teoria dos direitos humanos, o constitucionalismo e a economia liberal. Provavelmente, esses núcleos foram o resultado daquilo que Merquior chamou de "diferença vocacional entre os teóricos do liberalismo" (1991, p. 9). Seja como for, o liberalismo, nas suas diversas versões, sempre propagou um Estado mínimo, absenteísta, enaltecendo as liberdades individuais e o papel negativo (não-intervencionista) do Estado e, consequentemente, de suas funções.

O Poder Judiciário por sua vez irá refletir os valores de um Estado Liberal, assumindo uma postura passiva. O julgador, na perspectiva liberal, limita-se a dizer o direito, e a jurisdição confunde-se com declaração de direitos, sem se questionar sobre a realização desses direitos. Baptista da Silva (1997), há tempos, insiste nessa perspectiva, denunciando o perfil liberal e racionalista da jurisdição moderna assumiu.

O modelo liberal clássico do Estado de Direito esgotou-se, havendo a carência de orientação das condutas humanas para a promoção do desenvolvimento econômico e social. A sociedade passou a exigir a presença de um Estado intervencionista (Garcia-Pelayo, 1982, p. 23) ${ }^{15}$. O cenário que se ergueu com o pós-guerra foi decisivo para ditar novos rumos.

Foi ficando cada vez mais difícil reduzir o direito ao direito estatal exclusivamente. A internacionalização econômica, política e social provocou a aproximação de sistemas jurídicos e, principalmente, o desvelamento de novos direitos. Paralelamente, inicia-se um movimento de revisão das fontes do direito com o questionamento da supremacia da lei/legislador e da força do princípio (formal) da legalidade (Sundfeld, 1992, p. 54).

indivíduo através do pacto escrito. Por fim, a soberania popular, menos relevante que o constitucionalismo, era a afirmação do poder absoluto da vontade geral, tratada por Rousseau (Macridis, 1982, p. 46-52).

14 As liberdades econômicas, ou seja, o núcleo econômico do liberalismo acabou assumindo uma importância maior, considerando que o mercado é o ponto de encontro de várias vontades individuais, no qual são feitas as relações contratuais. É nesse núcleo que estarão compreendidos os direitos de propriedade privada, a liberdade de produção, as liberdades contratuais, a economia de mercado livre, sem intervenção estatal (Macridis, 1982, p. 40).

15 Dallari refere que, apesar de o Estado Liberal, com um mínimo de interferência na vida social, ter trazido, de início, alguns inegáveis benefícios (valorização do indivíduo, desenvolvimento da ideia de poder legal a sobrepor-se à ideia de poder pessoal), o próprio modelo liberal criou as condições para a sua própria superação (Dallari, 2000). 
Nesse cenário, não era mais possível prescindir-se de uma postura interventiva do Estado sobre o domínio socioeconômico. O reflexo foi o progressivo alargamento das funções públicas e a transição do Estado Liberal de Direito para o Estado Social de Direito, permanecendo alguns caracteres essenciais do Estado Absolutista e outros do Estado Liberal, como a base nacional-territorial, a unificação administrativa, o arcabouço constitucional e a referência aos direitos e garantias fundamentais (Saldanha, 1987, p. 112.). Insere-se, no entanto, um novo componente, qual seja, a função social.

No Estado Social de Direito, o seu conteúdo jurídico passa a ser a questão social, visando ao bem-estar geral e dispondo-se a controlar os aspectos econômicos, sociais e culturais da sociedade (Garcia-Pelayo, 1982, p. 24). Sobre essa nova roupagem do Estado de Direito, Garcia-Pelayo (1982, p. 56) vai afirmar que não só se incluem direitos para limitar a ação do Estado, como também direitos a serem prestados pelo Estado, que, naturalmente, deverão obedecer a um princípio de eficácia, o que exige a harmonização entre a racionalidade jurídica e a racionalidade técnica.

Não obstante as discrepâncias e sinais de transformação, há que se trazer a lume o fato de que o núcleo básico em ambas as formulações estatais - Liberal e Social - não se altera. O Estado Liberal e o Estado Social apresentam certa similitude (Streck, 2014, p. 91) no que tange à finalidade última; em ambas as situações, o fim ultimado é a adaptação à ordem estabelecida (Bolzan de Morais, 1996, p. 83).

$\mathrm{Na}$ sequência de transformações verificadas no Estado de Direito, percebe-se que a garantia de liberdades negativas, privilegiando o indivíduo, e a promoção de liberdades positivas, atendendo ao bem-estar comum, deixaram de ser suficientes para suprir os anseios da sociedade da época, a qual passava a reivindicar uma pretensão à igualdade. Deu-se, assim, uma tentativa de transformação do status quo com o acréscimo do elemento democrático ao Estado de Direito: emergia a pretensão de um Estado Democrático de Direito.

Os modelos do Estado Liberal de Direito e do Estado Social de Direito não conseguem dar conta das progressivas e constantes demandas sociais, em especial no âmbito do ideal de liberdade e igualdade, da limitação do poder, da proteção e implementação dos direitos. A preocupação básica do 
Estado Democrático de Direito "é a transformação do status quo" (Bolzan de Morais, 1996, p.74). O Estado Democrático de Direito (Streck, 2014, p.90) possuía a pretensão de um "conteúdo transformador da realidade", distinguindo-se do Estado Social de Direito, que visava à "adaptação melhorada das condições sociais de existência”. O Estado Democrático de Direito representava "vontade constitucional de realização do Estado Social" (Streck, 2011, p.39).

A dificuldade dos regimes democráticos de se confrontarem com a crescente desigualdade socioeconômica e a multiplicação dos problemas sociais, em particular a violência e a beligerância, exigiram e sobrecarregaram o Estado, revelando a insuficiência do Poder Legislativo, a ineficiência do Poder Executivo e a incipiência do Poder Judiciário. Emerge o paradoxo democrático: o Estado democrático se consolidou, mas não da forma esperada, constituindo-se assim uma democracia inesperada (Sorj, 2004).

Some-se a esse diagnóstico o importante papel inesperado que o Estado democrático de direito atribuiu ao Poder Judiciário. Nicola Picardi (2008, p. 116), apontando as conexões entre jurisdição, legislação e administração, evidencia a "vocação do nosso tempo para a jurisdição", a qual resta perceptível a partir do significativo incremento dos poderes do juiz, alçado a controlar o exercício das funções dos poderes legislativo e executivo, gerando, não raro, conflitos institucionais. Picardi (2008) conclui que as relações entre juiz, estado e comunidade transformaram-se neste século XXI, pondo em xeque a função da jurisdição e a atuação do juiz.

As premissas sobre as quais se erigiram o prometido Estado Democrático de Direito e a transição de um século vocacionado ao legislativo para um século vocacionado ao judiciário, mostram-se hoje defensáveis para o esperado Estado Democrático de Direito?

Talvez, tenha razão Calvino (1990, p. 20), quando ao comentar o romance de Kundera afirma que "na vida, tudo aquilo que escolhemos e apreciamos pela leveza acaba bem cedo se revelando de um peso insustentável”. A leveza se tornaria insignificante? 


\section{A INSUSTENTÁVEL INSIGNIFICÂNCIA DA LEI E OS MODELOS DE REALIZAÇÃO DO DIREITO: AFINAL, TODOS OS UMBIGOS SÃO IGUAIS?}

A leveza, na narrativa de $A$ festa da insignificância, aponta para o solipsismo. A fluidez do vai e vem das personagens denuncia a fragilidade dos significados e ao apelo à repetição banalizada dos sentidos ressignificados. O umbigo da sociedade atual é o poder judiciário. Como definir o sentido do direito, da jurisdição e da democracia, numa época em que nossa atenção está concentrada no umbigo? Se o Poder Judiciário, desde o final do século XX, tornou-se um dos principais alvos da atenção da sociedade contemporânea. No contexto nacional, é possível afirmar que o Poder Judiciário brasileiro nunca foi tão discutido pela sociedade quanto agora. Está na pauta da mídia a discussão sobre a judicialização da política e dos conflitos, a morosidade da Justiça, a ineficiência/insuficiência da prestação jurisdicional, os custos de um processo, os vencimentos dos juízes, as posições assumidas pelos julgados, as arbitrariedades das decisões e corrupções dentro do Judiciário. Tudo isso (a transparência) reflexo de um contexto democrático, mas também de uma situação paradoxal: de um lado, o grande apelo e importância atribuídos ao Poder Judiciário; de outro, a intensa e crescente insatisfação com a atuação desse poder, objeto de críticas e de ceticismo.

O tempo da modernidade é um tempo em/de crise. O direito da modernidade é um direito em/da crise. Uma nova forma de atuar o direito exige uma nova forma de atuar (e compreender) a jurisdição e novas atitudes dos juristas. Ressignificar sem banalizar! Uma jurisdição eminentemente repressiva e reparadora não atende (mais) ao sentido do direito. O direito não é algo em geral, em abstrato, mas é substância, é princípio. Não basta reparar a lesão a direitos ou a violação de direitos, é preciso preveni-las a violação de direitos e proteger o sentido do direito. Não parece existir divergência quanto a isso na doutrina. A discrepância, todavia, está entre o discurso de um direito e a prática de um direito, o que pode claramente ser percebido examinando-se os bancos acadêmicos e a práxis forense. A reprodução de um senso comum oculta o sentido do 
direito, transformando juristas em mitläufer jurídicos ${ }^{16}$, que, incapazes de criar um direito, reproduzem receitas de um direito sem sentido (e sem tempo) ou, pior, de um direito funcionalizado, instrumento do poder ou de governo (Castanheira Neves, 1998).

$\mathrm{Na}$ sociedade contemporânea, complexa e conflituosa, os antigos modelos calcados no paradigma racionalista e no paradigma liberalindividualista-normativista estilhaçaram-se (Streck, 2004; Streck, 2011), exigindo do Estado, da sociedade e do direito a revisão de seus modelos de pensamento e dos seus padrões de conduta ${ }^{17}$. É com a crise dos paradigmas da modernidade que ocorre uma (nova) ruptura, não para reinserir o presente no cerne das preocupações de todos, mas para inverter a ordem da temporalidade e revisar o papel do jurista e da jurisdição.

Talvez até tenhamos superado os componentes essenciais do paradigma dominante dos séculos XIX e XX, quais sejam: as certezas, as ilusões e os determinismos. Talvez tenhamos tido êxito em repensar o direito a partir das seis propostas de Ítalo Calvino (1990): da leveza, da rapidez, da exatidão, da visibilidade, da multiplicidade e da coerência. Esses compromissos, muito provavelmente, povoaram o imaginário do juiz nesta primeira década de século. A propósito disso: qual o balanço desta primeira década? Concentramo-nos no umbigo?

A questão não se trata de propor uma reflexão sobre como se processa a prestação jurisdicional, mas na direção do desvelamento do sentido do direito rumo à busca por novos paradigmas, por novos modelos de pensamento, por novas alternativas, tendo sempre o direito como uma alternativa humana (Castanheira Neves, 1995). O direito, assumida a sua dimensão hermenêutica, passa a demandar novos paradigmas, que, por sua vez, exigem novas formas de compreensão, que superem o direitoenquanto-sistema-de-regras e resgatem o mundo prático (faticidade) até então negado pelo positivismo e pelos valores liberais do Estado.

16 O uso da expressão é da autora. Mitläufer, em alemão, significa aquele que segue o comportamento da maioria, irrefletidamente; e é aqui empregado no intuito de referir o "senso comum teórico dos juristas", cunhado por Warat (1993, p. 101-104).

17 Importante registrar que a superação da crise do poder judiciário, enquanto sucedâneo da crise do próprio Estado, exige necessariamente uma nova rota, ou seja, é preciso trilhar o caminho das formas alternativas de tutela, com vistas a reduzir a litigiosidade. Segundo Baptista da Silva (2006), dois aspectos emergem nesse sentido: o ensino do direito e a redução do fator burocrático do Estado. 
Não problematizar a crise ou não investigar suas razões inviabiliza, por óbvio, a trajetória para a construção de suas alternativas, ou seja, inviabiliza o direito como alternativa humana diante da(s) crise(s) (Castanheira Neves, 1998).

No âmbito da concretização de direitos, em especial no contexto de uma sociedade plural, díspar, na qual a maioria dos cidadãos clama pela consolidação do Estado Democrático de Direito e pela realização de direitos, como é o caso da sociedade brasileira, é preciso voltar os olhos para a jurisdição, o poder judicial e o papel do juiz. Trata-se da defesa de uma jurisdição atenta à concretização dos princípios e garantias constitucionais. Uma jurisdição que ultrapasse os (pseudo)limites estabelecidos como fronteira entre a mera declaração de direitos (jurisdicção) e a sua realização (juris-construção ou juris-realização ou jurisdição criativa ou juriscriação). Uma jurisdição que recupere a autonomia normativo-intencional do direito perante a mera legalidade, bem como preencha o espaço dos limites normativo-jurídicos da lei, na realização concreta do direito, enquanto um continuum constituendo em função de uma dialética normativa que articula os princípios normativo-jurídicos com o mérito jurídico do problema concreto através da mediação das normas legais. Para fugir à alternativa entre o ceticismo e o dogmatismo, o risco que nos assombra é a sacralização do umbigo: o ativismo e o decisionismo ${ }^{18}$. Como defender a jurisdição? Como resolver o impasse e apostar numa democracia possível?

Para defender a jurisdição, é preciso também assumir o direito como uma ciência da compreensão e não como ciência da explicação, superando o peso do paradigma liberal-iluminista e do pensamento linear-cartesiano, ainda tão presentes no nosso dia-a-dia. Faz-se urgente buscar novas lentes para enxergar o direito, a jurisdição e a democracia que se espera e, consequentemente, as suas bases filosóficas, políticas e jurídicas. Há que se buscar a inventividade do direito, não a partir de um abstracionismo, mas sim a partir de uma inventividade substancialista do direito e do processo, visto que, se a normatividade só pode ser determinada realizando-se, faz-se

18 Sobre a crítica ao ativismo, consultar: Trindade; Morais, 2011. 
necessária uma compreensão prática e não simplesmente uma compreensão dogmática ou lógica dessa normatividade.

O resultado dessa releitura será a abertura de espaço para um novo cenário, para um novo paradigma hermenêutico ou, quiçá, para a libertação do direito dos grilhões paradigmáticos, reconhecendo que o direito nasce do fato e não da leiÉ preciso, no entanto, que estejamos dispostos a assumir o peso dessa escolha, suspendendo alguns prejuízos e desconfiando de algumas obviedades que se costumam reproduzir sem uma reflexão mais profunda. É preciso saber sustentar o peso das escolhas.

Ora, o desvelamento dos novos direitos - o processo de multiplicação de direitos - que se verifica a partir dos últimos séculos, seja pelo aumento de bens a serem tutelados, seja pelo aumento do número de sujeitos de direito ou ainda pela ampliação dos status dos sujeitos ${ }^{19}$, somados às alterações no perfil da sociedade brasileira e do Estado moderno (desde o modelo liberal clássico, passando pelo (ou saltando o) Estado Social, até chegar - ou pretender chegar - ao Estado Democrático de Direito), exige (a) que se questione o papel da jurisdição ante a concretização dos direitos e (b) que se reconheça a função social da jurisdição, superando a falsa ideia de que o processo se reduz a simples procedimento.

Esses problemas podem ser apresentados como pertencentes a duas categorias, conforme expõe Castanheira Neves (1998): são os problemas estruturais ou externos ao exercício da jurisdição e o problema intencional, ou seja, o problema do sentido, do sentido da jurisdição, o qual orienta a discussão a respeito do imaginário social sobre o juiz e da crise da jurisdição. Crise essa que se traduz na consumação histórico-cultural de um sistema, ou seja, perda contextual de sentido das referências até então regulativas. Para adotar uma terminologia que já faz parte do modismo intelectual, a crise representa o cenário de um paradigma que, antes em vigor, agora se esgotou, clamando por um novo paradigma, por um novo modelo de pensamento.

À luz da perspectiva substancialista, é evidente que o principal elemento fundante dos sistemas e dos paradigmas não se concentra na sua estrutura, mas antes no seu sentido, eis que, se a estrutura organiza e

\footnotetext{
19 Sobre a multiplicação dos direitos, consultar: Bobbio, 1998 e Oliveira Jr., 2000.
} 
permite o funcionamento do sistema ou de um paradigma, só o sentido funda e constitutivamente sustenta. Por essa razão, concorda-se com Castanheira Neves (1998) quando, enfaticamente, alerta que uma crise só pode ser superada pela reflexão fundadora de um novo sentido, ou seja, é a crítica que supera a crise. Se assim é, não há como fundar um novo sentido sem distinguir os problemas estruturais e o problema intencional, traçando uma reflexão acerca deles.

Os problemas estruturais - externos ao exercício da função jurisdicional - envolvem o poder, a organização, a responsabilidade e o modo desse exercício, mas não se referem à intencionalidade material da própria jurisdição como jurisdição e o sentido que ela assume e realiza. Os problemas envolvem, ainda, o modo do fazer jurisdicional, mas não "o que é" esse fazer ou "o que" nele se faz. São (a) os problemas diretamente político-constitucionais; (b) o problema institucional; e (c) o problema da legitimação decisória. Os problemas estruturais ou externos são condições de possibilidade da jurisdição que se pretende, mas o problema intencional ou interno compreende os momentos constitutivos da jurisdição, toca na essência, e não na forma; trata da substância, e não do procedimento. Assim, tem-se que a realização da essência está condicionada pela correta ou adequada solução dada aos problemas estruturais; a solução correta ou adequada será um correlato funcional do que seja ou se pretenda que seja a jurisdição enquanto tal. Como bem refere Castanheira Neves (1998), pensar o sentido da jurisdição é pensar a sua relação com o direito (juris-dictio), o que significa que um diferente sentido do direito implicará correlativamente um diferente sentido da jurisdição chamada a realizá-lo. Importa, portanto, mais que discutir problemas estruturais do poder judiciário e da jurisdição, investigar sobre o problema do sentido, do sentido da jurisdição, para que assim seja possível ressignificar o direito e a jurisdição e, consequentemente, o próprio imaginário social sobre o juiz e sobre o papel por ele desempenhado na realização da justiça.

Nesse sentido, Michele Taruffo (1999) aponta três linhas para uma reflexão orientada à superação dessa situação problemática. A primeira direção seria uma mudança na cultura processualista, que se sobreponha a atitudes obsoletas, formalistas da dogmática tradicional. A segunda direção é no sentido da recuperação e reformulação dos valores fundamentais e dos 
princípios gerais considerados válidos para o processo. A terceira direção está na redefinição da sistemática dos instrumentos de tutela processual. Essas três linhas nos conduziriam a uma reforma da jurisdição, mas não necessariamente a sua refundação (Espindola, 2012), com impactos significativos na construção do imaginário social sobre o juiz e seu papel.

Surge, portanto, a necessidade de uma nova forma de atuação do direito e dos juristas, que passa por quatro principais aspectos: (a) a recuperação de sentido do direito; (b) a recuperação do papel do poder (função) judicial; (c) a concretização jurídica e social dos direitos e (c) a rediscussão sobre a função da jurisdição. Portanto, para que se alcance algum contributo, não podemos nos furtar a uma investigação sobre o sentido do direito e sobre os modelos jurisdicionais de realização do direito, buscando, com isso, identificar indícios da superação de velhos paradigmas e diagnosticar caminhos possíveis.

Exatamente por isso a presente reflexão é o resultado teórico de preocupações práticas, que, na perspectiva heideggeriana, assume-se como uma atitude diante do mundo (uma "parada", no sentido heideggeriano) que faz com que esse estar-no-mundo seja alvo de questionamento.

Essa "parada" implica, para retomar a lição de Baptista da Silva, a investigação dos compromissos do direito e da jurisdição que o realiza com o paradigma dominante que transformou aquele em uma "ciência", sujeita aos princípios metodológicos das ciências duras, reduzido a um conjunto sistemático de conceitos, com pretensão de eternidade, desvinculado da História e do Homem. Para Baptista da Silva: "os juristas do direito material levam, a este respeito, uma apreciável vantagem sobre os que se dedicam ao direito que se realiza no tumulto da vida forense" (2007, p. 01).

Não basta - embora seja de vital importância para o debate - detectar a herança racionalista do direito. $\mathrm{O}$ dogmatismo sedimentado precisa ser superado, para que, só então, o direito recupere a sua dimensão hermenêutica, a sua perspectiva substancialista e, consequentemente, o seu sentido.

É preciso enfrentar o dogmatismo sedimentado, sem, contudo, cair no modismo da crítica ou do ceticismo, ou, no meio da multidão, perder-se na reprodução de sentidos: na festa da insignificância. Não basta navegar 
contra os ventos. Há que se navegar entre o Estado Democrático de Direito e a dimensão hermenêutica do direito, sem perder de vista o Homem, vez que é ele e para ele servem as garantias de prevalência do direito, numa perspectiva substancialista, e incluir a dimensão do tempo nos esquemas discursivos.

A condição problemática do direito na contemporaneidade "não exprime senão uma dimensão da nossa própria problemática situação histórico-existencial; situação em que nós mesmos, com todos os sentidos da nossa cultura e herança constituinte, nos pomos em causa até o limite" (Castanheira Neves, 2002, p. 47). A realidade jurídica caracteriza-se, como anuncia Castanheira Neves, por uma evolutiva perda de sentido do direito, ou parafraseando Milan Kundera: uma verdadeira festa da insignificância.

Não se trata de apresentar soluções, mas antes de um "problematizar o problema" da realização da justiça, sem ocultar a fragilidade quer das reformas processuais propostas pelo establishment quer das construções doutrinárias, eis que reproduzem o paradigma dominante, sem problematizá-lo, sem revelá-lo, sem um “dar-se conta”, sem o necessário enfrentamento da crise de paradigmas que assola o direito e a jurisdição, que, ao fim e ao cabo, reduzem o essencial à futilidade, à banalidade, à mundanidade.

Para fugir à alternativa entre o ceticismo e o dogmatismo, alguns vetores destacam-se, quais seja: (a) a recuperação da autonomia normativointencional do direito perante a mera legalidade, na medida em que há uma renovada distinção entre lex e ius, seja através da preferência jurídica dos direitos (fundamentais) perante a lei, seja pelo reconhecimento de princípios normativos translegais (que transcendem a lei/legalidade); e (b) o reconhecimento de limites normativo-jurídicos da lei (os limites objetivos, os limites intencionais e os limites temporais) (Castanheira Neves, 1998, p. 5 e 12-13). Torna-se já impossível continuar a identificar o direito com a legislação, bem como a idealizar o poder judicial como um poder nulo, acético, insípido. Daí falar-se na necessária revisão do problema das fontes do direito e do princípio da separação dos poderes.

O reconhecimento de limites normativo-jurídicos forja uma jurisdição que vai se dar pela realização concreta do direito, em necessária "intenção normativamente constituenda", como refere Castanheira Neves em diversas 
obras. Esses limites desvelam, ao mesmo tempo que balizam, o espaço do poder judicial, da jurisdição e do papel do juiz. O direito legalmente positivado não alcança a dinâmica social, ficando aquém do domínio histórico-socialmente problemático a que terá de responder jurídiconormativamente. Isso significa que esse limite objetivo exige um desenvolvimento autônomo do direito através da sua própria realização, ou seja, da sua jurisprudencial realização. De outro lado, existem limites intencionais que conduzem a reconhecer que a realização do direito está para além de um sentido lógico-dedutivo e formal, apresentando-se como insuficiente a subsunção da lei ao caso. A realização do direito vai assumir um sentido normativamente material, mostrando-se concretamente adequada ao mérito problemático dos casos decidendos e normativamente justificada em referência aos fundamentos axiológico-normativos que dão sentido normativo material ao próprio direito. Por fim, há também os limites temporais, catalogados por Castanheira Neves (1998, p. 8) ao lado daqueles limites objetivos e intencionais. Os limites temporais, assim, surgem do reconhecimento da dimensão histórica do direito e do seu sistema normativo. O positivismo, em qualquer de suas vertentes, vai ignorar essa dimensão histórica, operando a partir de uma racionalidade lógico-abstrata revestida por uma subsistência atemporal, a-histórica. O resultado da desconsideração desses limites é, parodiando a partir do romance de Kundera, a sacralização do umbigo.

Duas alternativas emergem. De um lado, a opção por uma sobrevalorização da estratégica político-social, assumindo-se o político como o único protagonista e, consequentemente, a função judicial como operador tático, através de meios institucionais e normativo-decisórios; ou seja, a jurisdição passa a ser instrumento dessa estratégia político-social ou longa manus. E, de outro lado, a opção por uma disputa entre poderes, de afirmar o direito ao poder, de reconhecer o direito como dimensão constitutivamente indefectível do Estado e, assim, o Estado verdadeiramente como Estado de Direito. Nesse caso, a universalidade de certos valores e princípios normativos em que todos se reconheçam é irrenunciável. É nessa universalidade axiológico-normativa que se traduz a autonomia do direito, reconhecendo-se no direito a "medida de poder". Ao reconhecer-se essa autonomia do direito, há que se chamar uma instância 
para contrapor-se à unidimensionalidade (ou totalitarismo) do político, qual seja: o poder judicial, a jurisdição, fundamentada no texto constitucional, e não exclusivamente na consciência do julgador. Resta clara, portanto, a opção assumida por essa segunda alternativa, que se contrapõe à perspectiva de uma jurisdição enquanto mero instrumento a serviço da estratégia político-social, na qual o político é o único protagonista.

Mas, ainda assim, o problema do sentido da jurisdição não se põe como solucionado. É preciso agora investigar sobre os modelos de juridicidade e seus correlativos modelos de jurisdição. Castanheira Neves identifica três modelos atualmente alternativos de realização jurisdicional do direito, os quais se apresentam entre o legislador, a sociedade e o juiz. Estes três modelos são: o normativismo legalista, o funcionalismo jurídico e o jurisprudencialismo.

O Racionalismo, posto como pano de fundo do normativismo legalista, passa a ser a expressão da ratio moderna - uma razão autofundada em seus axiomas e sistematicamente dedutiva nos seus desenvolvimentos; uma razão que deixa de ser ontológico-metafísicohermenêutica como a razão clássica; uma razão como sistema, uma razão cartesiana. No contexto dessa visão de mundo, a visão de homens livres, racionais e, na sua liberdade, também iguais, exigia-se a institucionalização de um novo poder, cujo sentido fundante estaria no contrato social. um contrato social perspectivado por Thomas Hobbes, por John Locke, por Jean-Jacques Rousseau ou por Immanuel Kant. A consequência, por certo, desse novo sentido fundante, aquele que o contrato constituísse, seria a constituição de uma legalidade: o direito reduzido à lei.

Foram a crise do normativismo legalista e as modificações ocorridas na cultura europeia no início da modernidade que abriram espaço para um novo modelo de judicialidade: o funcionalismo jurídico ${ }^{20}$. Esse modelo de realização do direito assume como referencial não mais o indivíduo (como o faz o normativismo legalista) ou uma associação atomística de indivíduos, mas sim a sociedade, teorizada enquanto sistema social pensado

${ }^{20}$ Integra-se, no âmbito do funcionalismo jurídico, o Critical Legal Studies Movement. 
funcionalmente, um sistema que funcionaliza todos os seus elementos e as suas dimensões, inclusive o próprio direito.

O pensamento moderno, entre os séculos XVIII e XIX, trouxe uma nova compreensão sobre o ser. Essencialmente diferente do pensamento clássico, o moderno se enraíza na história. Rompe-se com os compromissos platônico-aristotélicos e a atitude contemplativa perante o ser. O homem moderno viu-se perante um mundo de faticidade empírica e de causalidade, axiologicamente neutro ${ }^{21}$, e a modernidade associou-se, dentre outros, à ideia de que o mundo é passível de transformação pela intervenção humana e, portanto, as ações sociais dos indivíduos são mediadas por algum tipo de interesse com um sentido objetivo: outra racionalidade passou a permear todo o agir social.

Ora, a racionalidade invocada pelo funcionalismo jurídico, na verdade, consiste em uma racionalidade finalística (zweckracionalitat), não-axiológica (wertrationalitat), para falarmos com Max Weber (1994). $\mathrm{Ou}$, ainda, de uma razão como instrumento, sob um aspecto utilitarista: uma razão instrumental na perspectiva de Max Horkheimer (1976). A preocupação primeira da perspectiva funcionalista não está em saber particularmente o que é o direito, mas, sim, para que serve: o direito reduzido a instrumento, a procedimento.

Embora a perspectiva do funcionalismo (e suas variantes) possa trazer algumas contribuições, em especial no contraponto que faz aos compromissos ideológicos assumidos pelo normativismo legalista, ela peca por projetar o direito como mero instrumento a serviço de finalidades externas ao direito. A decisão judicial, na concepção funcional do direito, é vista como a realização de uma estratégia político-social, teleologicamente programada. É a decisão-solução enquanto momento tático. Perspectiva essa sedutora, exatamente no contexto atual, em que o homem se preocupa com a eficiência, a utilidade, o dano, porém ignora, não raro, o conteúdo e a materialidade de suas ações. Isso poderá conduzir o direito à arbitrariedade, na medida em que o direito nada mais terá a falar, visto que, na sua generalidade e realização concreta, é condicionalmente determinado pelos interesses política ou socialmente mais adequados. O direito é afinal

21 As influências de Descartes e Leibniz foram determinantes para essa ruptura com o pensamento clássico e para uma nova compreensão do ser. 
puramente política, no funcionalismo político; simplesmente tecnologia ou administração, no funcionalismo social e econômico. Veja-se que o funcionalismo jurídico não envolve as funções que o direito exerce na sociedade, mas antes as funções que se pretendem realizar através dele. Assim, pretender conferir funções ao direito ou realizar sua função não significa que se esteja assumindo uma opção pela perspectiva funcionalista, mas, antes, uma opção pelo próprio direito e pelo homem, ou seja, uma opção antropológico-cultural da qual dependerá o sentido do direito e a sua subsistência enquanto tal (Castanheira Neves, 1998, p. 31-32)22.

O jurisprudencialismo, trazido por Castanheira Neves como contraponto aos radicalismos dos dois modelos anteriores (normativismolegalista e funcionalismo jurídico), orienta-se por uma perspectiva polarizada no homem-pessoa, sujeito da prática problemática-judicanda, e assumido como a reafirmação/recuperação do sentido da prática jurídica como iuris-prudentia: "axiológico-normativa nos fundamentos; práticonormativa na intencionalidade e judicativa no modus metodológico" (Castanheira Neves, 2010, p. 62). O jurisprudencialismo parte de uma perspectiva do homem-pessoa, ou seja, de uma perspectiva em que o direito está diretamente a serviço de uma prática pessoalmente titulada e historicamente concreta (Castanheira Neves, 1998, p. 15 e 32). Nega-se, assim, a identificação da pessoa ao "indivíduo" e recusa-se o individualismo para desvelar a responsabilidade ética perante a pessoa em todo o universo humano, bem como a responsabilidade ética da pessoa relativamente a esse universo. Dito de outro modo, “a pessoa não é só sujeito de direitos, sejam eles fundamentais ou outros, mas simultaneamente sujeito de deveres" (Castanheira Neves, 1998, p. 33). E mais: não são os direitos simples reivindicações politicamente sustentadas, tampouco os deveres

${ }^{22}$ Contrapondo com a Festa da insignificância e a cena em que Alan pensa sobre o umbigo, pode-se dizer que em determinada época o centro das reflexões sobre o direito girava em torno da lei positivada (direito reduzido à lei), devendo o juiz, após um longo e sofisticado processo judicial, marcado por um juízo de cognição exauriente e plenária, desvelar a vontade do legislador: as pernas (o centro de sedução nessa época eram as coxas enquanto metáfora da magia romântica do inacessível. No momento seguinte, Alan reflete sobre o que definiu a orientação erótica das pernas para a bunda e os seios. O direito, antes reduzido à lei, passa a legitimar-se pelo procedimento, instrumentalizando-se, o "caminho mais curto em direção ao objetivo". Essa funcionalização retira a autonomia do direito, esvaziando-o de sentido. Mas o que dizer do atual momento, quando o centro das atenções está voltado para o centro do corpo, o umbigo: o juiz? $\mathrm{O}$ direito está reduzido à decisão/consciência do juiz? 
exterioridades limitativas só pelo cogente cálculo dos interesses e sempre repudiavelmente sofridos, como acontece com a polarização prática do indivíduo, mas manifestações mesmas da axiologia responsável e responsabilizante da pessoa.

Nessa perspectiva, uma concepção da jurisdição, da função judicial e do papel do juiz passam, necessariamente, pela recompreensão do próprio homem, de seus compromissos, passa pelo reconhecimento comunitário da pessoa e da sua dignidade ética, mas também assume implicações normativas, consequentes desta recompreensão e reconhecimento. Tratase, nas palavras de Castanheira Neves, de uma "exigência de fundamento", exigência essa que, enquanto expressão de uma ratio, manifestação de um sentido, ou de um princípio transindividual, está implicada no postulado do sujeito ético e na intenção de um social compromisso prático em que a racionalidade não advém de um teórico universal sistemático, mas de uma prática fundamentação normativa material. Trata-se daquilo que Castanheira Neves (1998, p. 32) designa por "consciência axiológiconormativa da consciência jurídica geral da comunidade histórico-cultural”.

Essa compreensão faz crer uma opção diversa, que não se enquadra nem no jusnaturalismo, tampouco no positivismo jurídico. Assume-se o direito como "uma resposta culturalmente humana ao problema também humano da convivência no mesmo mundo e num certo espaço históricosocial" (Castanheira Neves, 2010, p. 62) sem a necessidade ou a indisponibilidade ontológica, mas sim com a historicidade e a condicionalidade de toda a cultura. O direito não é, portanto, um dado, um “descoberto" pela "razão teorética”, mas, antes, é constituído por exigências humano-sociais particulares explicitadas pela "razão prática”. E mais: não trata simplesmente do resultado normativo de uma voluntas orientada por um finalismo de oportunidade ou a mera expressão da contingência e dos compromissos político-sociais, haja vista que a prática jurídica (decorrente também de uma prática histórico-cultural) convoca constitutivamente, na sua normatividade, certos valores e certos princípios normativos fundantes de certa cultura em certa época. Recusa-se, assim, a lei como critério jurídico para a decisão concreta, eis que se exige uma autônoma constituição da solução jurídica - que não se identifica nem se esgota no texto legal. 
É exatamente a dialética entre o sistema e o problema concentrados no objetivo judicativo de realização normativa que desenha a racionalidade jurídica do jurisprudencialismo - racionalidade essa atenta à intenção de justeza material em relação ao problema (numa perspectiva substancialista), sem, contudo, ignorar a intenção de concordância normativa (que não se resume ao texto legal, mas o transcende, para alcançar os princípios normativos).

Assim, o alargamento e aprofundamento da experiência problemática, enquanto experiência também histórica, não causa estranheza, mas, antes, a angústia do estranhamento, para falar com Heidegger. A mudança permanente nos horizontes de expectativa do homem está implicada em novas intenções que, através de novos problemas e novos sentidos às respostas, vão sendo assumidas, demarcando a capacidade hermenêutica do direito (Trindade; Morais, 2011). Não se admite uma sobrevalorização do sistema que se traduza no axioma de que os problemas a emergir serão unicamente aqueles suscitados tal qual idealizados. Novas perguntas (problemas) surgem, e outros sentidos para as respostas, implicados em novas intenções, são assumidos: o direito realiza-se na sua possibilidade de vir-a-ser, em constante tensão com o tempo. O direito não é um dado, ou um objeto, mas, antes, um problema - um "contínuo problematicamente constituendo" (Castanheira Neves, 1995, p. 38). Exatamente por isso cumpre a ele ultrapassar o jurídico positivo e, como dito, recusar o texto de lei ou a consciência do julgador como critério jurídico para a decisão concreta. Isso implica um diálogo problemático entre a norma (enquanto normativa solução abstrata de um pressuposto problema jurídico tipificado) e as exigências normativas específicas do caso decidendo compreendido autonomamente.

Assim, o jurisprudencialismo assume o paradigma da jurisdição centrado no juízo e não na subsunção lógico-dedutivista ou na simples decisão. Juízo esse que não se identifica com um qualquer raciocínio lógico, mas que, antes, realiza o sentido prático de julgar. É um juízo da ponderação prática, de índole prático-argumentativa, que assume como 
critério fundamentos ${ }^{23}$. É preciso alertar, no entanto, que o argumento não é, nessa perspectiva, uma premissa, não se trata de uma proposição pressuposta de uma inferência necessária, tampouco de mera subsunção lógico-dedutiva. Trata-se, antes, de juízos axiológico-normativamente críticos sobre o objeto problemático de resolução, cuja principal função social está na afirmação de valores em seu concreto cumprimento. A perspectiva normativa é imanente e o seu tempo é o presente (não o passado, como na perspectiva legalista, nem o futuro, como na perspectiva funcionalista), sendo indispensável o juiz e a sua responsabilidade ética de projeção comunitária. O papel a ser assumido pelo juiz não é o de mero funcionário, servidor passivo do legislador ou simples burocrata, mas daquele que assume para si uma responsabilidade ética, que constitui o direito como expressão humana.

O itinerário não se assenta em "essências" ou em "a prioris" ontológicos, mas assume a perspectiva do homem-pessoa e a defesa da jurisdição estatal, enquanto instituição indispensável à prática de um regime verdadeiramente democrático, incorporando a dimensão do tempo na compreensão hermenêutica do direito, porque afinal, os umbigos não são todos iguais.

\section{REFERÊNCIAS}

AGRA, Walber de Moura et al. Comentários à reforma do poder judiciário. Rio de Janeiro; Forense, 2005.

ARENDT, Hannah. Eichmann em Jerusalém: um relato sobre a banalidade do mal. Tradução de José Rubens Siqueira. São Paulo: Companhia das Letras, 2000.

BAPTISTA DA SILVA, Ovídio A. Jurisdição e execução na tradição romano-canônica. Rio de Janeiro: Forense, 1997.

BAPTISTA DA SILVA, Ovídio A. Jurisdição, direito material e processo. Rio de Janeiro: Forense, 2007.

BAPTISTA DA SILVA, Ovídio A. Processo e ideologia: o paradigma racionalista. Rio de Janeiro: Forense, 2006.

BOBBIO, Norberto. A era dos direitos. Tradução de Carlos Nelson Coutinho. Rio de Janeiro: Elsevier, 2004.

\footnotetext{
23 Esses fundamentos não são considerados premissas ou efeitos, mas fundamentos em que a normatividade do sistema da validade se manifeste e se determine, como bem refere Castanheira Neves (1998, p. 41).
} 
BOBBIO, Norberto; MATTEUCCI, Nicola; PASQUINO, Gianfranco. Dicionário de política. Tradução de Carmen C. Varrial. Brasília: UnB, 1998.

BOLZAN DE MORAIS, José Luis. Do direito social aos interesses transindividuais: o estado e o direito na ordem contemporânea. Porto Alegre: Livraria do Advogado, 1996.

BOLZAN DE MORAIS, José Luis. Mediação e arbitragem: alternativas à jurisdição. 2. ed. Porto Alegre: Livraria do Advogado, 2008.

CANOTILHO, José Joaquim Gomes. Direito constitucional e teoria da constituição. 3. ed. Coimbra: Almedina, 1999.

CAPPELLETTI, Mauro. Juízes irresponsáveis. Tradução de Carlos Alberto Alvaro de Oliveira. Porto Alegre: Safe, 1989.

CASTANHEIRA NEVES, António. Metodologia jurídica. Coimbra: Coimbra Editora, 1993.

CASTANHEIRA NEVES, António. Direito hoje e com que sentido? O problema actual da autonomia do direito. In: CASTANHEIRA NEVES, António. (Org.). Digesta: escritos acerca do direito, do pensamento jurídico, da sua metodologia e outros. Coimbra: Coimbra Editora, 2010. v. 3, p. 4372

CASTANHEIRA NEVES, António. Digesta: escritos acerca do direito, do pensamento jurídico, da sua metodologia e outros, v. 1. Coimbra: Coimbra Editora, 1995 .

CASTANHEIRA NEVES, António. Entre o "legislador", a "sociedade" e o "juiz" ou entre "sistema", "função" e "problema": os modelos actualmente alternativos da realização jurisdicional do direito. Boletim da Faculdade de direito da Universidade de Coimbra, Coimbra, v. LXXIV, (separata), 1998.

CASTANHEIRA NEVES, António. O direito hoje e com que sentido? Lisboa: Instituto Piaget, 2002

DALLARI, Dalmo de Abreu. Elementos de teoria geral do estado. 21. ed. São Paulo: Saraiva, 2000.

ESPINDOLA, Angela Araújo da Silveira. A refundação do direito processual civil e os três desafios à dogmática processual: a tutela preventiva, a tutela coletiva e a virtualização do judiciário. Revista de Processo, v. 203, p. 207234, 2012.

ESPINDOLA, Angela Araújo da Silveira; SILVA, Jaqueline Mielke da. Direito processual civil à luz das novas exigências de tutela do século XXI: a insuficiência do positivismo jurídico para resolver os conflitos sociais contemporâneos. Revista Eletrônica Direito e Política, v. 9, p. 1005-1028, 2014 .

FERRAJOLI, Luigi. Derechos fundamentales; los fundamentos de los derechos fundamentales. Madrid: Trota, 2001.

FERRAJOLI, Luigi. Pasado y futuro del Estado de derecho. In: CARBONELL, Miguel. Neoconstitucionalismo(s). Madrid: Trotta, 2003. p. 187-210.

FERREIRA FILHO, Manoel Gonçalves. Estado de direito e constituição. 2. ed. São Paulo: Saraiva, 1999. 
FISS, Owen. Um novo processo civil. Tradução de Carlos Alberto de Salles. São Paulo: Revista dos Tribunais, 2004.

GARCIA-PELAYO, Manuel. Las transformaciones del estado contemporáneo. 3. ed. Madrid: Alianza, 1982.

HAYEK, Friedrich August Von. Los fundamentos de la libertad. 5. ed. Madrid: Union, 1991.

HORKHEIMER, Max. Eclipse da razão. Tradução de Carlos Henrique Pissardo. Rio de Janeiro: Labor do Brasil, 1976.

LEAL, Rogério Gesta. Perspectivas hermenêuticas dos direitos humanos e fundamentais no Brasil. Porto Alegre: Livraria do Advogado, 2000.

LEFORT, Claude. Nação e soberania. In: NOVAES, Adauto (Org.). A crise do estado-nação. Rio de Janeiro: Civilização Brasileira, 2003. p. 55-78.

MACRIDIS, Roy. Ideologias políticas contemporâneas. Tradução de Marcos Santarrita. Brasília: UNB, 1982.

MANNHEIM, Karl. Diagnóstico de nosso tempo. Tradução de Octavio Alves Velho. Rio de Janeiro: Zahar, 1967.

MERQUIOR, José Guilherme Alves. O liberalismo antigo e moderno. Rio de Janeiro: Nova Fronteira, 1991.

MIRANDA, Jorge. Teoria do estado e da constituição. Rio de Janeiro: Forense, 2002.

OLIVEIRA JR., José Alcebíades. Teoria jurídica e novos direitos. Rio de Janeiro: Lumen Juris, 2000.

PERELMAN, Chaïm. Ética e direito. Tradução de Maria Ermantina de Almeida Prado Galvão. São Paulo: Martins Fontes, 1996.

PICARDI, Nicola. Jurisdição e processo. Rio de Janeiro: Forense. 2008.

ROTH, André-Noël. O direito em crise: fim do estado moderno? In: FARIA, José Eduardo. Direito e globalização econômica: implicações e perspectivas. São Paulo: Malheiros, 1996. p. 15-27.

ROUSSEAU, Jean-Jacques. O contrato social. 3. ed. Tradução de Paulo Neves. São Paulo: Martins Fontes, 1996.

SALDANHA, Nelson. Pequeno dicionário da teoria do direito e filosofia política. Porto Alegre: Safe, 1987.

SALINAS FORTES, Luiz Roberto. Rousseau: o bom selvagem. São Paulo: FTD, 1989.

SCAFF, Fernando Facury. Responsabilidade civil do Estado intervencionista. Rio de Janeiro: Renovar, 2001.

SORJ, Bernardo. A democracia inesperada: cidadania, direitos humanos e desigualdade social. Rio de Janeiro: J. Zahar, 2004.

STRECK, Lenio Luiz. Jurisdição constitucional e hermenêutica. 2. ed. Rio de Janeiro: Forense, 2004.

STRECK, Lenio Luiz. Verdade e consenso. 3. ed. Rio de Janeiro: Lumen Juris, 2009. 
STRECK, Lênio Luiz. Hermenêutica jurídica e(m) crise. 10. ed. Porto Alegre: Livraria do Advogado, 2011.

STRECK, Lênio Luiz; BOLZAN DE MORAIS, José Luiz. Ciência política e teoria geral do estado. 8. ed. Porto Alegre: Livraria do Advogado, 2014.

SUNDFELD, Carlos Ari. Fundamentos do direito público. São Paulo: Malheiros, 1992.

TARUFFO, Michele. Racionalidad y crisis de la ley procesal. Doxa: Cuaderno de Filosofia del Derecho, n. 22, p. 311-320, 1999.

TRINDADE, André Karam; MORAIS, Fausto Santos de. Ativismo Judicial: as experiências norte-americana, alemã e brasileira. Revista da Faculdade de Direito (UFPR), v. 53, p. 57-84, 2011.

TRINDADE, André Karam. A filosofia no direito e as condições de possibilidade para se compreender os fenômenos jurídicos. Paradigma (Ribeirão Preto), v. 22, p. 258-268, 2013.

TRINDADE, André Karam; MORAIS, Fausto Santos de. Ensaio sobre a crítica hermenêutica do direito: uma reconstrução do pensamento jurídico de Lenio Streck. Revista do Instituto de Hermenêutica Jurídica, v. 10, p. 107-130, 2011.

WARAT, Luiz Alberto. Introdução crítica ao direito, v. 1. Brasília: UnB, 1993.

WEBER, Max. Economía y sociedad. 10. ed. México: Fondo de Cultura Económica, 1994.

WOLKMER, Antonio Carlos. Ideologia, estado e direito. São Paulo: Revista dos Tribunais, 1989.

ZAGREBELSKY, Gustavo. El derecho dúctil. 5. ed. Madrid: Trotta, 2003.

ZAGREBELSKY, Gustavo. Historia y constitución. Madrid: Trotta, 2005.

ZIPPELIUS, Reinhold. Teoria geral do estado. 3. ed. Tradução de Karin Praefke-Aires Coutinho. Lisboa: Fundação Calouste Gulbenkian, 1997. 